\title{
Has the acceptance of the equality and freedom principles increased over 15 years? A comparative analysis of attitudes among students
}

\section{KEYWORDS}

attitudes, democracy, the principle of equality and freedom

\begin{abstract}
Czerniawska Mirosława, Has the acceptance of the equality and freedom principles increased over 15 years? A comparative analysis of attitudes among students. Culture Society - Education no. 1(17) 2020, Poznań 2020, pp. 95-115, Adam Mickiewicz University Press. ISSN 23000422. DOI 10.14746/kse.2020.17.4.2
\end{abstract}

The publication deals with the description of attitudes towards the democratic principles of equality and freedom among students. The survey was conducted four times in five-year time intervals $(2003,2008,2013,2018)$. Samples had $325,379,368$, and 371 respondents respectively. The author speculated that the advancement of the transformation is accompanied by growth of the acceptance of prodemocratic attitudes among students, namely the wider acceptance of the principles of equality and freedom. The attitudes were diagnosed using nine pairs of statements (these include both original statements and statements adopted from literature). The hypothesis was not confirmed. The acceptance of the principles of equality and freedom has not increased in consecutive surveys and for many statements the acceptance has decreased.

* ORCID https://orcid.org/0000-0001-7311-5915. 


\section{Introduction}

Asked whether they agree with the statement that "democracy is superior to all other forms of government", Poles almost three to seven times as often reply affirmatively (depending on the survey year) rather than negatively. This indicator was calculated on the basis of 31 surveys of the CBOS Public Opinion Research Centre (2019: 1; the table shows the fraction of persons selecting one of the three response variants: "agree", "disagree", "hard to say"), spanning the years 1992-2019. The most positive attitude towards the democratic system was recorded in November 2007 (the statement was confirmed 6.7 times more than it was denied), with the least positive approach recorded in November 2015 (the statement was confirmed 2.6 times more than it was denied). However, in general, the share of persons agreeing with the statement that "democracy is superior to all other forms of government" always exceeded 50\% (being between 52\% and 76\%) and was higher than the total share of persons responding "disagree" or "hard to say".

"Democracy" is a term that usually gives rise to positive associations. This is because this is a system better facilitating individual development. The ideology aligned with democracy is based on two axiological pillars: "equality" and "liberty". The so-called democratic axioms that translate to rules governing relations in the political and social sphere are derived from these values. According to these, an individual - as a citizen of a specific country - has equal rights/ opportunities irrespective of their national, religious or sexual identity (this expresses discrimination-free state policy). They can also expect respect for autonomy and the right to make choices. This shines through in areas such as: freedom of speech, freedom of organisation, freedom of movement (including of foreigners to Poland) or the right to make personal decisions, including moral ones. A consequence of freedom perceived as such may be independence from influence by culture and religion and the acceptance of diversity.

The study presented in the article focuses on an analysis of student attitudes towards rules of democracy that stem from the values of "equality" and "liberty". It must be noted that a positive assessment of democracy ("democracy is superior to all other forms of government", conf. the above-quoted CBOS survey results, 2019) and the assignment of significant importance to the values quoted above does not mean the approval of all rules that constitute the properties of this system. This stems e.g. from the fact that the concept of "democracy" is defined variably by various people, sometimes drastically diverging from the textbook definition (e. g. it is associated with welfare states or financial wealth, conf. Reykowski, 1995). In addition, the acceptance of principles of democracy requires a "democratic" 
personality type, hence one characterised by openness, flexibility of thinking and tolerance for diversity, a high level of internal control and unconventionality, the ability to enter into compromises, rational political attitudes and an active attitude in life, the lack of enmity, acknowledgement of equality among people and subjective treatment of all citizens. This is a characteristic akin to the self-actualising personality of A. Maslow and the post-material mentality of R. Inglehart (Czerniawska, 2010). According to the latter, the principles constituting this type of mentality gain traction as the wealth of society increases (elimination of factors directly threatening physical or economic existence), and they are conditioned upon the presence of democratic institutions and their relation to a specific type of political culture (Frąckowiak-Sochańska, 2009).

\section{Research problem and hypotheses}

The present study assumes democracy to be understood as "a synonym of civic rights and duties" (Ludwikowski, 1998). It was assumed that two core value "equality" and "liberty" - give rise to certain rules governing relations in the political and social sphere (conf. Czerniawska, 2010). Student attitudes were diagnosed against the rules of equality of rights/ opportunities (equal rights of national, religious, sexual minorities and allowing foreigners to perform gainful work) and liberties (openness to the world, right to organise in social and political organisations irrespective of the state, freedom of speech and of public expression, personal freedoms, for instance the right to make decisions concerning abortions and euthanasia). The attempt was made to assess, with respect to which issues and which category of people their application is justified. The study was conducted four times (four groups of students with similar properties), e. g. in the years 2003, 2008, 2013 and 2018, using the same research tool. The values acquired in course of this study were covered by a comparative analysis. It was assumed that with the solidification of institutions of the democratic state (this process has a history of almost 30 years in Poland), pro-democratic attitudes are also solidified, e.g. the share of students accepting rules of equality and liberty increases (hypothesis no. 1).

The comparative analysis of attitudes diagnosed in the years 2003 and 2008 was presented in earlier publications (Czerniawska, 2010; 2011). The present article uses information published there as well as portions of text (including the mode of interpretation of the rules of equality and liberty), in order to show changes in attitudes in the years 2013 and 2018. An analogous structure of descriptions of study results was used as well. 


\section{Method}

Study group. The study encompassed 1443 persons, of which $325(22.52 \%)$ - in the year 2003, $379(26.26 \%)$ - in the year 2008, 368 (25.50\%) - in the year 2013 and 371 $(25.72 \%)$ - in the year 2018. The four groups were homogenised in the following terms:

- field of education: ca. $50 \%$ of the study group spanned paedagogy students of the University of Białystok, and ca. $50 \%$ were students of management of the Białystok University of Technology;

- study mode: full-time studies;

- education level: first, second and third year students;

- gender: quantitative majority of women (ca. 80\%);

- age: ca. $90 \%$ of those surveyed were students aged 20-21.

Taking into account the characteristics of the four study groups presented above, one could surmise that they are characterised by a more or less homogeneous scope of knowledge about the socio-political reality, by a comparative intellectual level, similar interests - related to the field of study and period of development as well as similar interpersonal relations (character of social relations). They would in turn differ in terms of experiences related to functioning in the new political reality with 14, 19, 24 and 29 years having elapsed since the year 1989 - hence, from the beginning of the political and economic transformation. The study was anonymous. Research tools. The present paper diagnoses attitudes on the basis of a set of views related to the rules of democracy. Respondents from the four groups (the years 2003, 2008, 2013 and 2018) voiced their remarks on nine pairs of statements. Each pair contains two opposing views. It was the task of the surveyed persons to assess these views, e. g. choose one of two options, the one that to a greater extent reflects the views of the individual concerning the issues at hand. In this manner, it was determined, to which category of phenomena and persons the rules of equality and liberty should apply. The attitudes numbered 2, 4, 6, 8 and 9 were created by the study author. Statements (or their fragments) making up attitudes no. 1, 3, 5 and 7 were taken from the work by J. Reykowski (1993) entitled Wartości i postawy Polaków a zmiany systemowe [Values and attitudes of Poles versus the systemic changes]. It must be stressed that the statements used in the study are modified (to a varied extent) in terms of content (conf. Czerniawska, 2011). The statements are included in table 1 and in figures 1-9.

\section{Results}

Table 1 shows the number of people choosing one of the two options of attitudes $(1,2)$ and the results of the statistical analysis by the $\chi^{2}$ test. 


\begin{tabular}{|c|c|c|c|c|c|c|c|c|c|c|c|}
\hline \multirow{6}{*}{ 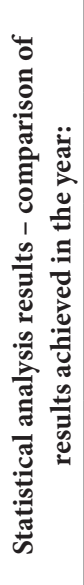 } & \multirow{3}{*}{ 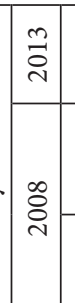 } & $\stackrel{\infty}{\stackrel{\sim}{*}}$ & 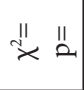 & \multicolumn{2}{|l|}{ 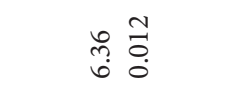 } & \multicolumn{2}{|c|}{ 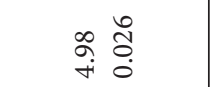 } & \multicolumn{2}{|c|}{ 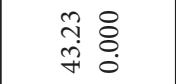 } & \multicolumn{2}{|c|}{$\begin{array}{ll}\hat{0} & \dot{m} \\
\dot{\lambda} & \dot{q}\end{array}$} \\
\hline & & $\underset{\sim}{\stackrel{\infty}{\sim}}$ & 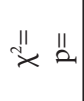 & \multicolumn{2}{|l|}{ 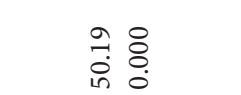 } & \multicolumn{2}{|c|}{ 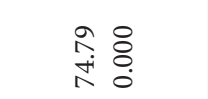 } & \multicolumn{2}{|c|}{ 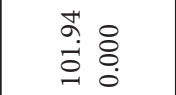 } & \multicolumn{2}{|c|}{$\begin{array}{ll}\vec{n} & \dot{m} \\
0 & \dot{q}\end{array}$} \\
\hline & & $\stackrel{m}{\stackrel{n}{\sim}}$ & $\begin{array}{ll}\| \prime \prime & \| \\
x & 0 .\end{array}$ & \multicolumn{2}{|l|}{$\begin{array}{l}\stackrel{0}{\infty} \\
\dot{\sim} \\
\dot{\sim} \\
0\end{array}$} & \multicolumn{2}{|c|}{ 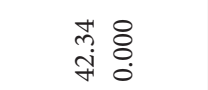 } & \multicolumn{2}{|c|}{ 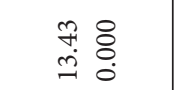 } & \multicolumn{2}{|c|}{ 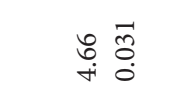 } \\
\hline & & $\stackrel{\infty}{\stackrel{\sim}{\sim}}$ & $\begin{array}{ll}\| 1 & \| 1 \\
& 2\end{array}$ & \multicolumn{2}{|l|}{ 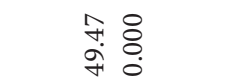 } & \multicolumn{2}{|c|}{$\begin{array}{l}=8 \\
= \\
\dot{8} \\
0\end{array}$} & \multicolumn{2}{|c|}{ 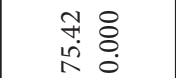 } & \multicolumn{2}{|c|}{$\begin{array}{ll} & 0 \\
\infty & 0 \\
\text { in } & 0\end{array}$} \\
\hline & 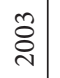 & $\stackrel{m}{\stackrel{n}{\sim}}$ & 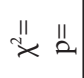 & \multicolumn{2}{|c|}{ 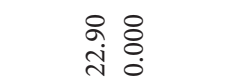 } & \multicolumn{2}{|c|}{$\begin{array}{l}\text { ก̂ } \\
\text { กิ } \\
\text { in } \\
\text { in }\end{array}$} & \multicolumn{2}{|c|}{ 今̊ } & \multicolumn{2}{|c|}{ 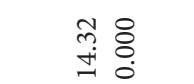 } \\
\hline & & $\begin{array}{l}\infty \\
\stackrel{0}{0} \\
\stackrel{\sim}{*}\end{array}$ & $\begin{array}{ll}\| \prime & \| \\
* & 2\end{array}$ & \multicolumn{2}{|l|}{$\begin{array}{ll}\vec{H} & \dot{m} \\
\dot{0} & \dot{\pi}\end{array}$} & \multicolumn{2}{|c|}{$\begin{array}{ll}\vec{N} & \dot{m} \\
\vec{N} & \dot{d}\end{array}$} & \multicolumn{2}{|c|}{ 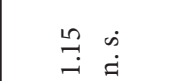 } & \multicolumn{2}{|c|}{$\begin{array}{l}8 \\
8 \\
\dot{m} \\
\dot{m}\end{array}$} \\
\hline \multirow{4}{*}{ 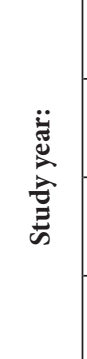 } & \multicolumn{3}{|c|}{$\stackrel{\infty}{\stackrel{\sim}{\sim}}$} & 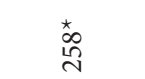 & $\stackrel{M}{=}$ & ટ્స & 10 & ț & 今ิ & ఏ & $\stackrel{\infty}{\infty}$ \\
\hline & \multicolumn{3}{|c|}{$\stackrel{m}{\stackrel{n}{N}}$} & $\underset{\infty}{*}$ & $\infty$ & $\stackrel{\sim}{\sim}$ & $\stackrel{\leftrightarrow}{\sim}$ & $\overrightarrow{\mathrm{n}}$ & $\triangleq$ & oิ & ๖ \\
\hline & & $\stackrel{\infty}{\stackrel{0}{0}}$ & & $\stackrel{\star}{\text { लै }}$ & के & ্ָণ & in & ?ి & 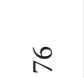 & $\underset{\text { ¿゙ }}{ }$ & $\stackrel{\llcorner}{\subseteq}$ \\
\hline & & ڤ̊ํํ & & ‡ి & Әे & $\underset{\sim}{\infty}$ & $\stackrel{\infty}{m}$ & 국 & 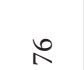 & $\stackrel{2}{\circ}$ & సิ \\
\hline & 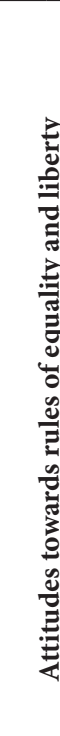 & & & 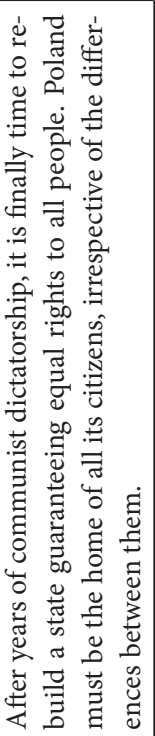 & 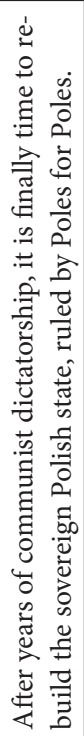 & 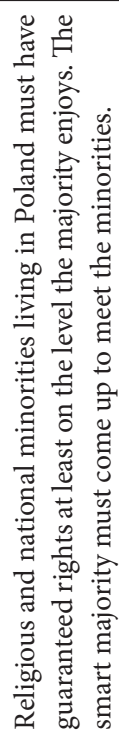 & 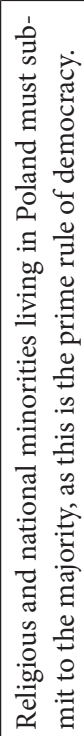 & 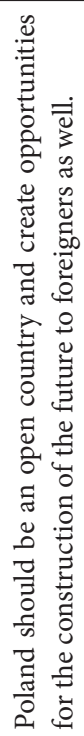 & 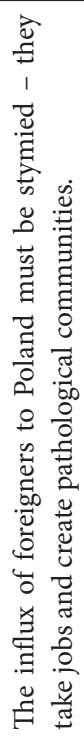 & 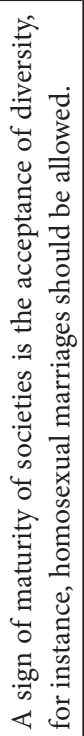 & 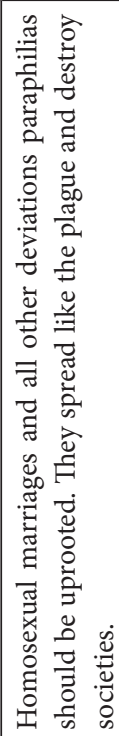 \\
\hline & & & & $-r$ & $N$ & - & $N$ & - & $N$ & - & $v$ \\
\hline & $\stackrel{0}{Z}$ & & & $\rightarrow$ & & $\sim$ & & & & & $r$ \\
\hline
\end{tabular}




\begin{tabular}{|c|c|c|c|c|c|c|c|c|c|}
\hline \multirow{6}{*}{ 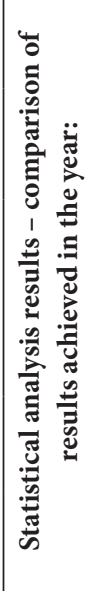 } & \multirow{2}{*}{\multicolumn{2}{|c|}{ 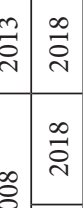 }} & \multirow{2}{*}{ 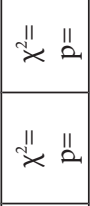 } & \multicolumn{2}{|c|}{$\begin{array}{ll}\overrightarrow{0} & \dot{m} \\
0 & \dot{a}\end{array}$} & \multicolumn{2}{|c|}{ 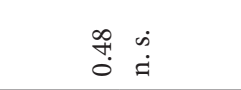 } & \multicolumn{2}{|c|}{ 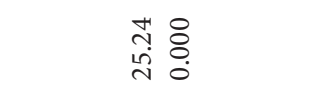 } \\
\hline & & & & \multicolumn{2}{|c|}{$\begin{array}{ll}\vec{b} & \dot{m} \\
\dot{0} & \dot{\pi}\end{array}$} & \multicolumn{2}{|c|}{ 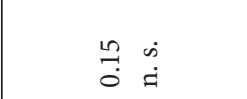 } & \multicolumn{2}{|c|}{ 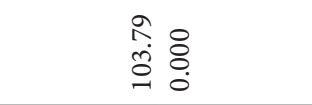 } \\
\hline & & $\stackrel{n}{\stackrel{n}{\sim}}$ & 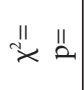 & \multicolumn{2}{|c|}{$\begin{array}{ll}\stackrel{\infty}{\circ} & \dot{0} \\
0 & \dot{\pi}\end{array}$} & & \multicolumn{2}{|c|}{ 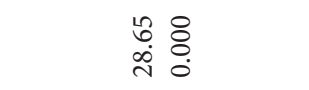 } \\
\hline & \multirow{3}{*}{ ְ̂̀ } & $\stackrel{\infty}{\stackrel{\sim}{*}}$ & $\begin{array}{ll}\| \prime \prime \\
x & 2\end{array}$ & \multicolumn{2}{|c|}{ 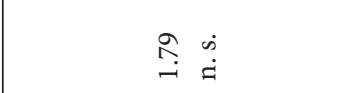 } & \multicolumn{2}{|c|}{ ๙઼ } & \multicolumn{2}{|c|}{\begin{tabular}{l}
7 \\
\multirow{3}{*}{$:$} \\
0
\end{tabular}} \\
\hline & & $\stackrel{m}{\stackrel{n}{*}}$ & 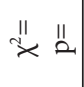 & \multicolumn{2}{|c|}{$\stackrel{\text { in }}{\dot{n}} \stackrel{\dot{m}}{\dot{4}}$} & \multicolumn{2}{|c|}{ 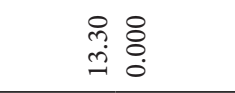 } & \multicolumn{2}{|c|}{$\begin{array}{l}\sharp \overrightarrow{8} \\
\stackrel{0}{0}\end{array}$} \\
\hline & & 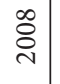 & 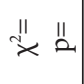 & \multicolumn{2}{|c|}{$\begin{array}{ll}\stackrel{n}{n} & \dot{n} \\
\dot{N} & \dot{\pi}\end{array}$} & \multicolumn{2}{|c|}{ 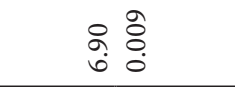 } & \multicolumn{2}{|c|}{$\begin{array}{ll}\stackrel{0}{0} \\
\infty \\
\dot{r} & 0\end{array}$} \\
\hline \multirow{4}{*}{ 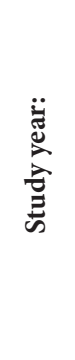 } & \multicolumn{3}{|c|}{ ๙ें } & 年 & $\underset{N}{ }$ & $\overrightarrow{\widehat{N}}$ & ¿ & $\stackrel{\oslash}{\bumpeq}$ & 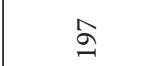 \\
\hline & \multicolumn{3}{|c|}{$\stackrel{m}{\stackrel{\sim}{\sim}}$} & $\stackrel{m}{m}$ & $\stackrel{\mathscr{n}}{\sim}$ & 太 & $\bar{a}$ & $\underset{\sim}{\stackrel{N}{N}}$ & 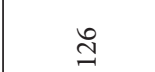 \\
\hline & \multicolumn{3}{|c|}{ 衣 } & $\vec{n}$ & $\stackrel{\infty}{\sim}$ & $\underset{\sim}{\mathbb{N}}$ & $\hat{\circ}$ & $\stackrel{H}{m}$ & 12 \\
\hline & \multicolumn{3}{|c|}{ ڤ̊̀ } & $\stackrel{\circ}{\circ}$ & $\stackrel{2}{n}$ & ֻे & $\widetilde{త}$ & ஷ̊ำ & $\stackrel{i n}{R}$ \\
\hline & \multirow{2}{*}{\multicolumn{3}{|c|}{ 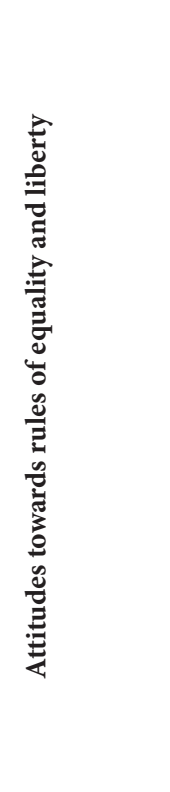 }} & 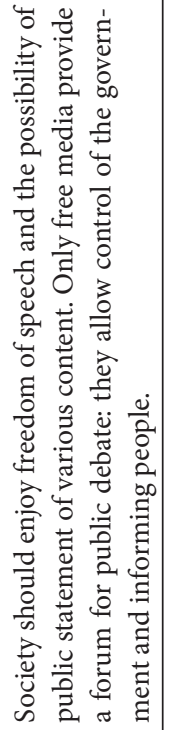 & 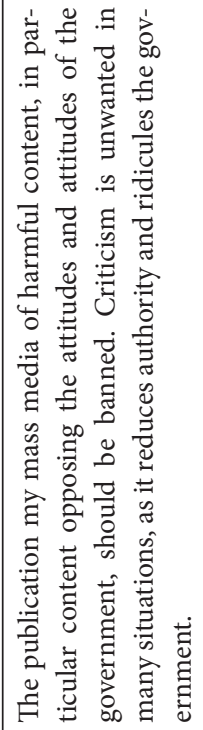 & 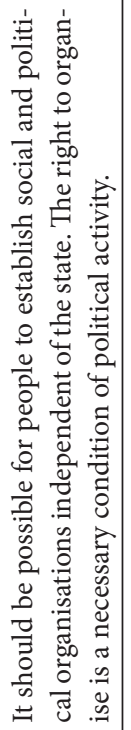 & 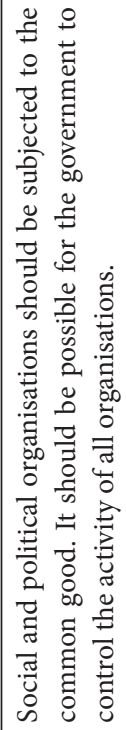 & 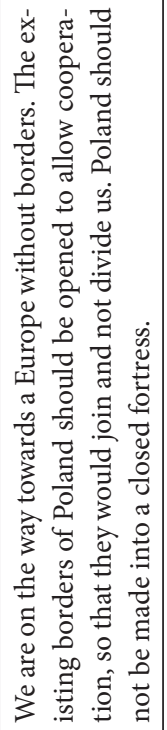 & 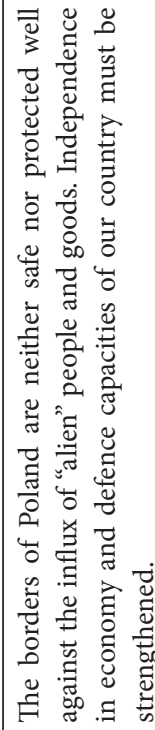 \\
\hline & & & & - & $v$ & - & $\sim$ & - & $v$ \\
\hline & \multicolumn{3}{|c|}{$\dot{z}$} & \multicolumn{2}{|r|}{ in } & \multicolumn{2}{|c|}{6} & \\
\hline
\end{tabular}




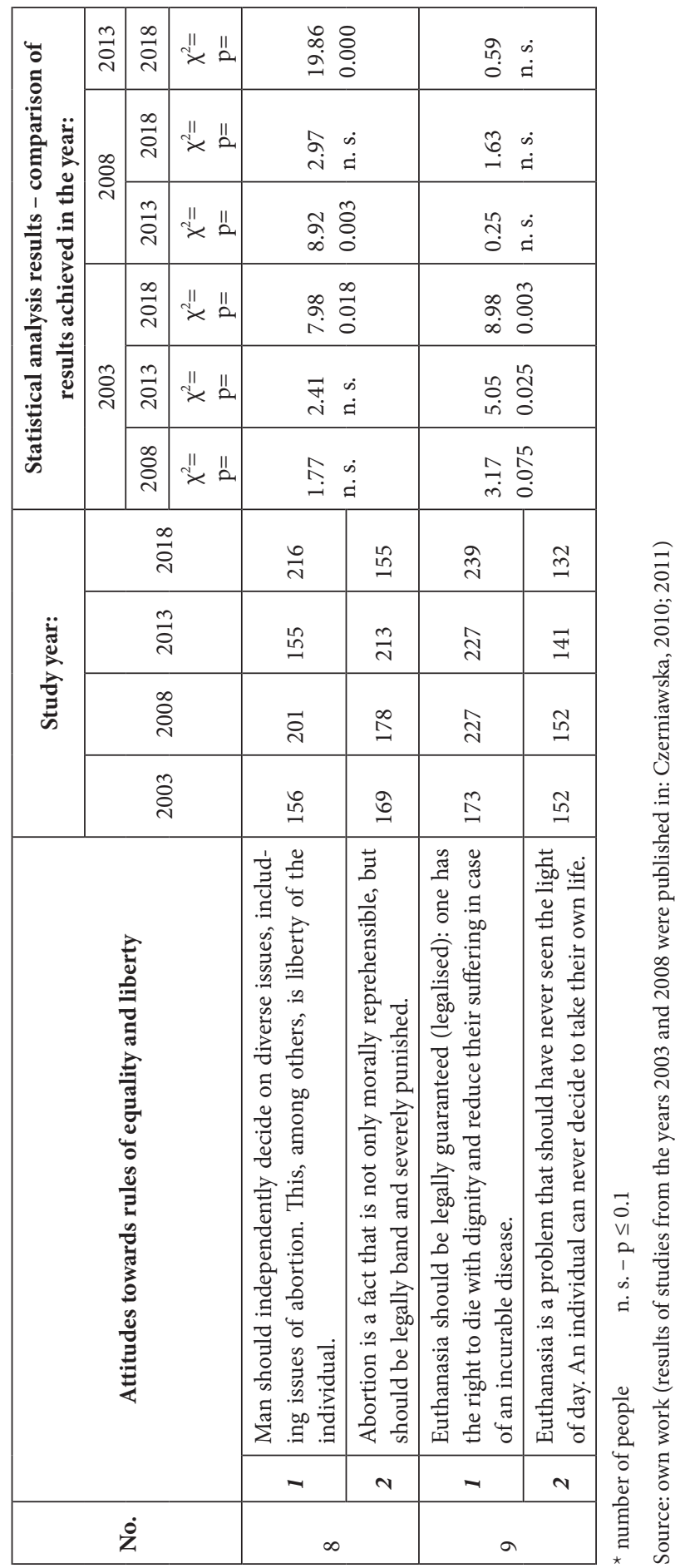




\section{Attitudes towards equality rules}

The key slogan of democracy is "equality". The implementation of this value facilitates the reduction of domination in interpersonal relations, the establishment of peaceful relations and the development of individuals. One of the most important tests, by way of which one can determine the level of a society's democratisation, is the analysis of the attitude towards "others", that is - foreigners and national, religious or sexual minorities. According to the principles of democracy, persons belonging to the minority (save for foreigners with an unregulated status) should have full rights, including the right to protect their own identity (Beetham, Boyle, 1994). One of the axioms of democracy is that the rule of the majority may not violate the autonomy of the minority.

The study attempted to diagnose the students' attitude towards the slogan "Poland for Poles", and hence determine the level of acceptance of the idea of a national state.

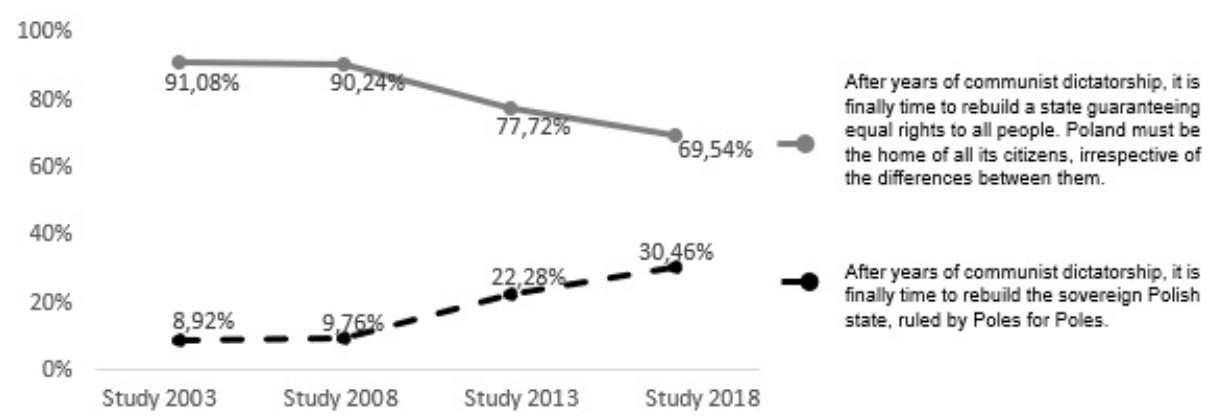

Fig. 1. Comparison of study results from the years 2003, 2008, 2013 and 2018: attitude 1

Source: own work (results of studies from the years 2003 and 2008 were published in: Czerniawska, 2010; 2011)

Students studied in the years 2003, 2008, 2013 and 2018 were mostly proponents of the option that Poland should be the home of all its citizens, irrespective of the differences that divide them $(91.08 \%, 90.24 \%, 77.72 \%$ and $69.54 \%$, respectively). A minority of students accepted in the years 2003 (8.92\%) and 2008 (9.76\%) the view that the state should be "governed by Poles for Poles" (conf. fig. 1). There were no statistically significant differences between these groups (conf. table 1). The share of youths representing such an attitude, however, increased in the last two surveys. Hence, in the year 2013, this attitude was represented by $13 \%$ more students than in the year 2003 and by $12.5 \%$ more than in the year 
2008. In the year 2018, this attitude was found in $21.5 \%$ more students than in the year 2003, in $20.7 \%$ more than in the year 2008 and in $8.2 \%$ more than in the year 2013. The differences were found at the required statistical significance level (conf. table 1).

Democracy is related to state policy free of discrimination against religious and national minorities.

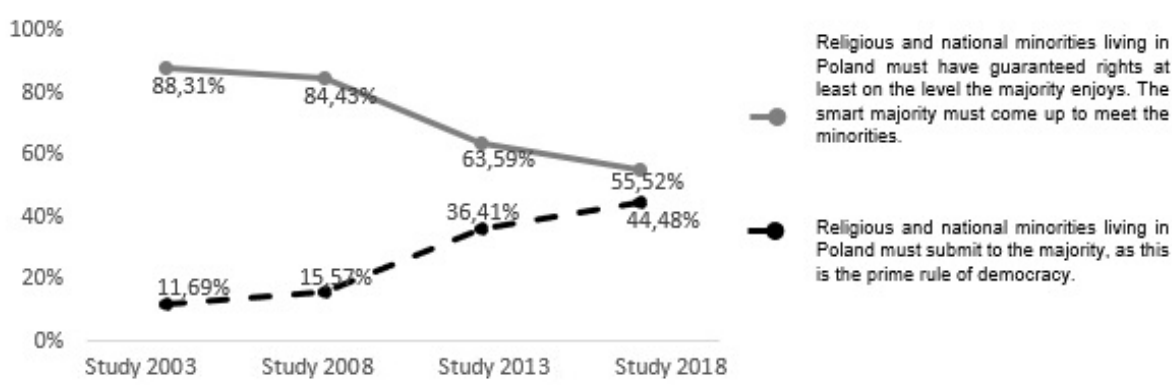

Fig. 2. Comparison of study results from the years 2003, 2008, 2013 and 2018: attitude 2 Source: own work (results of studies from the years 2003 and 2008 were published in: Czerniawska, 2010; 2011)

The number of supporters of the guarantee of equal rights for these groups was as follows: $88.31 \%$ students surveyed in the year 2003, $84.43 \%$ in the year 2008 , $63.59 \%$ in the year 2013 and $55.52 \%$ in the year 2018. At the same time, $11.69 \%$, $15.57 \%, 36.41 \%$ and $44.48 \%$ of respondents respectively supported the opinion that national and religious minorities should submit to the majority (conf. fig. 2). The indicators for the first and second study do not differ. In the third and fourth study - as compared to the two earlier ones - a higher proportion of students was against the application of the democratic rule of equality with respect to the analysed minority groups. The most significant numbers were recorded for the last survey. Comparing the surveyed group from the year 2013 with the two previous ones, differences of ca. $24.7 \%$ and $20.8 \%$ were found; comparing the group of 2018 with the three previous ones - differences of $32.8 \%, 28.9 \%$ and $8.1 \%$ were recorded (conf. table 1).

The next diagnosis analysed attitudes towards foreigners, however, this time they were deemed to be those who are the competition on the job market, in particular in terms of lower wage costs. 


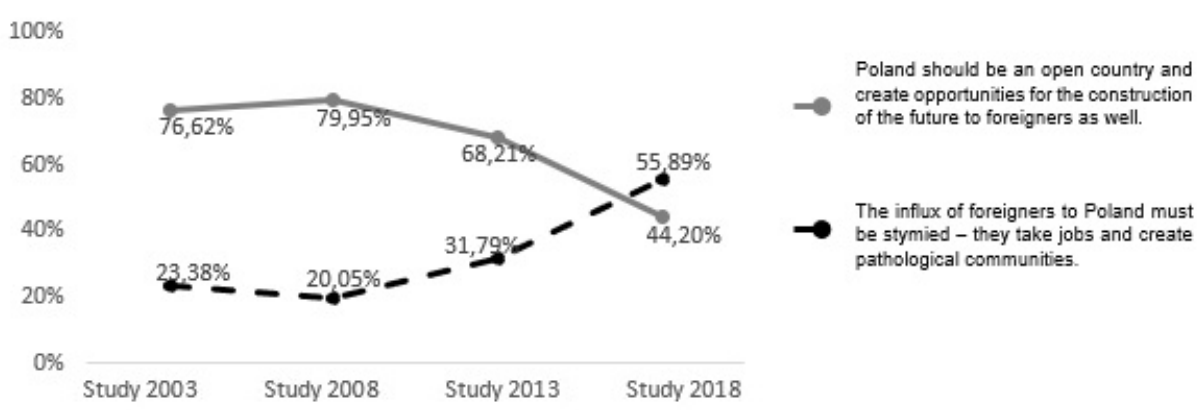

Fig. 3. Comparison of study results from the years 2003, 2008, 2013 and 2018: attitude 3 Source: own work (results of studies from the years 2003 and 2008 were published in: Czerniawska, 2010, 2011)

Students participating in the first three surveys mostly supported $(76.62 \%, 79.95 \%$ and $68.21 \%$, respectively) the openness of Poland and the creation of opportunities for foreigners. In the last survey, however, they constituted a minority (44.20\%). Over $20 \%$ (23.38\% and 20.05\%) of respondents from the years 2003 and 2008 saw the need to reduce the influx of foreigners, seeing them as the cause of unemployment and social degradation. In case of these groups, no statistically significant differences were found (conf. table 1). The share of students representing such an attitude was $31.79 \%$ in the year 2013, hence, it rose by $8.4 \%$ compared to the year 2003 and by $11.7 \%$ compared to the year 2008. The highest value was found, however, in the year 2018, meaning, $51.21 \%$. It is higher by $32.4 \%$ as compared to the year 2003 , by $35.7 \%-$ compared to the year 2008 and by $24.0 \%$ - compared to the year 2013 (conf. fig. 3). The differences described above are statistically significant (conf. table 1).

The attitude towards "others" was also analysed on the level of customs and observances. An attempt was made to analyse attitudes towards homosexuals.

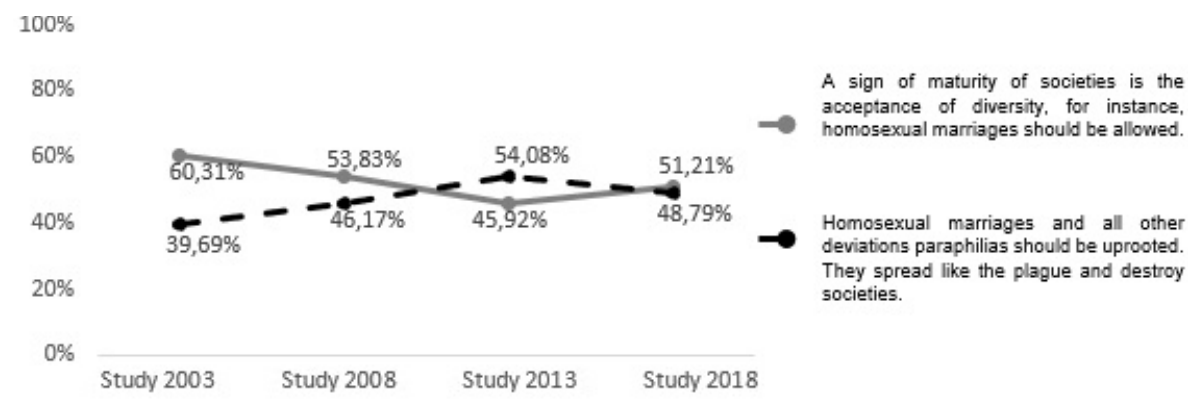

Fig. 4. Comparison of study results from the years 2003, 2008, 2013 and 2018: attitude 4 Source: own work (results of studies from the years 2003 and 2008 were published in: Czerniawska, 2010; 2011) 
The view that homosexual marriages should be legalised was held by $60.31 \%$ of respondents in the year 2003 , by $53.83 \%$ - in the year 2008 , by $45.92 \%$ - in the year 2013 and by $51.21 \%$ - in the year 2018 (conf. fig. 4). This indicates the level of acceptance of rights of sexual minorities. Negative attitudes towards the discussed issues were found relatively less frequently among "2003 students" (39.69\%) compared to all later survey group ("2008 students" - 46.17\%, "2013 students" - 54.08\%, "2018 students" - 48.79\%). The differences were $6.5 \%, 14.4 \%$ and $9.0 \%$, respectively (the first of these values at the limit of statistical significance). These attitudes were declared relatively less frequently by students in the year 2008 than by those in the year 2013 (difference of 7.9\%) (conf. table 1).

\section{Attitudes towards rules of freedom}

Democracy is identified with liberty, and more specifically - with a set of political, civic and social liberties: of conscience, faith, thought, views, speech and broadly perceived activity. It creates the possibility of open debate, expression of opinions (freedom of speech and of the press), undertaking own initiatives, free association of citizens looking to achieve specific objectives (Krzemiński, 2005). At the same time, liberty may not transgress the framework of the law, hence the law describes the level of freedom. Hence, the consequence in the adherence to civic liberties and rights is an indicator of democratic order (of a state's democracy).

Freedom of speech is understood as the right to expression with respect to broadly understood political issues and the expression of political interests. This includes criticism of officials, of the government, of the political system and of the prevailing ideology. This also applies to access to various sources of information and their legal protection (Dahl, 1995; Wasilewski, 2005). One could say that the level and mode of usage of freedom of speech indicates the establishment of democracy within a specific society.

The decisive majority of students spoke in favour of freedom of speech and the possibility of public expression of diverse content ("2003 students" - 95.38\%, “2008 students" - 92.61\%, "2013 students" - 93.21\%, "2018 students" - 93.00\%). A minor proportion of respondents ("2003 students" - 4.62\%, "2008 students" $7.39 \%$, "2013 students" - 6.79\%, "2018 students" - 7.00\%) expressed the view that certain content should not be disclosed, meaning, such that reduces the authority of government (conf. fig. 5). In the choice of attitudes no statistically significant differences were found (conf. table 1). Democratic changes in Poland saw much attention devoted to ideas related to freedom of speech. The significance of freedom of speech in this regard shone through in all groups, irrespective of the survey year. 


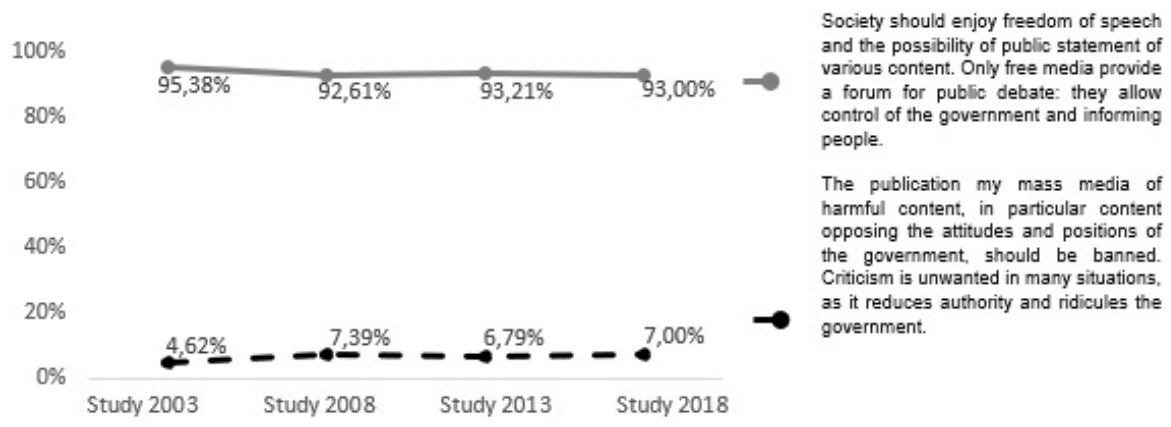

Fig. 5. Comparison of study results from the years 2003, 2008, 2013 and 2018: attitude 5 Source: own work (results of studies from the years 2003 and 2008 were published in: Czerniawska, 2010; 2011)

One of the significant determining factors for [political] system transformations is the establishment of a civic society based on a pluralism of organisations and voluntary, grassroots cooperation. Citizens should have the right to establish relatively independent organisations (including political parties), clubs, associations or foundations that permit the expression and agreement of interests of diverse social groups, control of governance, common activity towards the achievement of a specific objective and the improvement of the quality of social life. This right is described in contrast to the preceding model - the monocentric state which constituted a centrally-imposed organisation based on compulsion (Dahl, 1995; Bartkowski, Jasińska-Kania, 2002; Wasilewski, 2005; Radziewicz-Winnicki, 2008).

Attempting to diagnose views on the discussed issue, the youths were asked to take a stance towards the statements presented in the subsequent diagram:

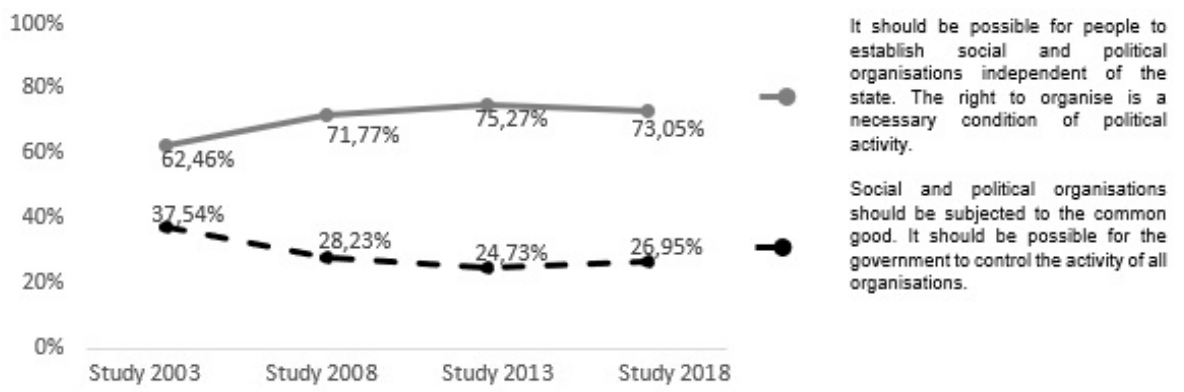

Fig. 6. Comparison of study results from the years 2003, 2008, 2013 and 2018: attitude 6 Source: own work (results of studies from the years 2003 and 2008 were published in: Czerniawska, 2010, 2011) 
The majority of respondents ("2003 students" - 62.46\%, "2008 students" 71.77\%, "2013 students" - 75.27\%, "2018 students" - 73.05\%) considered the right of citizens to freely associate as being just, treating it as a necessary condition for political activity. In turn, 37.54\% of participants of the first study, $28.23 \%$ - of the second one, $24.73 \%$ - of the third and $26.95 \%$ - of the fourth held the view that such organisations should be subjected to the common good, and that the government should be able to control them (conf. fig. 6). As can be seen, the attitude was relatively more popular among "2003 students" than among "2008 students" (difference of 9.3\%), "2013 students" (difference of $12.8 \%$ ) and "2018 students" (difference of 10.6\%). The required statistical significance level was attained during the comparison of the indicated groups (conf. table 1).

Within the context of the presented own research, differences were observed between groups when choosing the options of views "borders open for international cooperation" versus "border protection against the inflow of foreigners and foreign goods" and "strengthening of independence in economy and defence capacities".

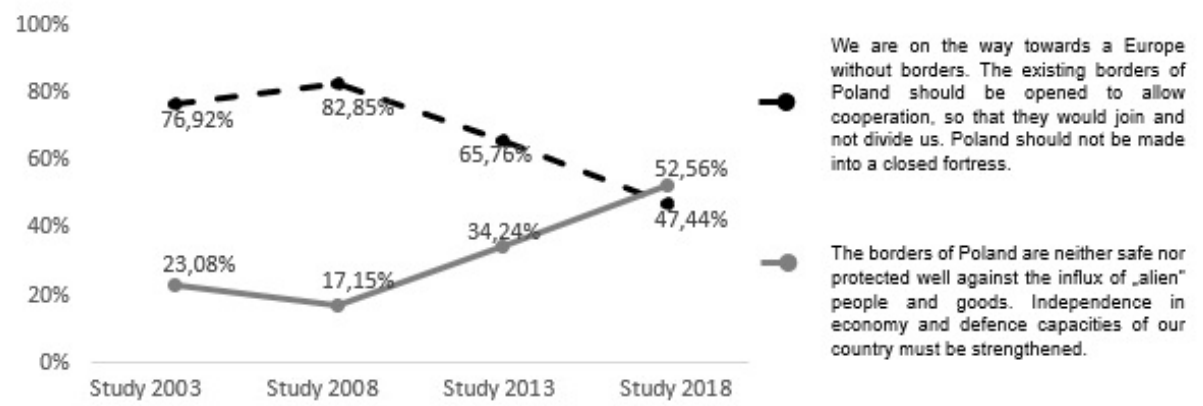

Fig. 7. Comparison of study results from the years 2003, 2008, 2013 and 2018: attitude 7 Source: own work (results of studies from the years 2003 and 2008 were published in: Czerniawska, 2010; 2011)

The following numbers of supporters of the opening of state borders in order to enable cooperation between nations were registered: $76.92 \%$ of students in the year 2003, $82.85 \%$ - in the year 2008, 65.76\% - in the year 2013 and $47.44 \%$ - in the year 2018. The necessity of protection of borders and enhancement of economic independence and the defence capacities of the country was indicated by $23.08 \%$, 
$17.15 \%, 34.24 \%$ and $52.56 \%$ of students respectively (conf. fig. 7). Comparing the values noted in the first two studies, one can see a drop in isolationist view prevalence (a difference of 5.9\%). It must be noted that the third of the discussed studies was conducted three years after Poland joined the EU, and its results may reflect the positive effects of that fact. In the last two studies, a significantly higher proportion of such convictions was noted as compared to the year 2003 (by $11.2 \%$ and $29.5 \%$, respectively), and in particular as compared to the year $2008(17.1 \%$ and $35.4 \%$, respectively) (conf. table 1 ).

The issue of personal liberties was considered by analysing the students' attitudes towards abortion and euthanasia.

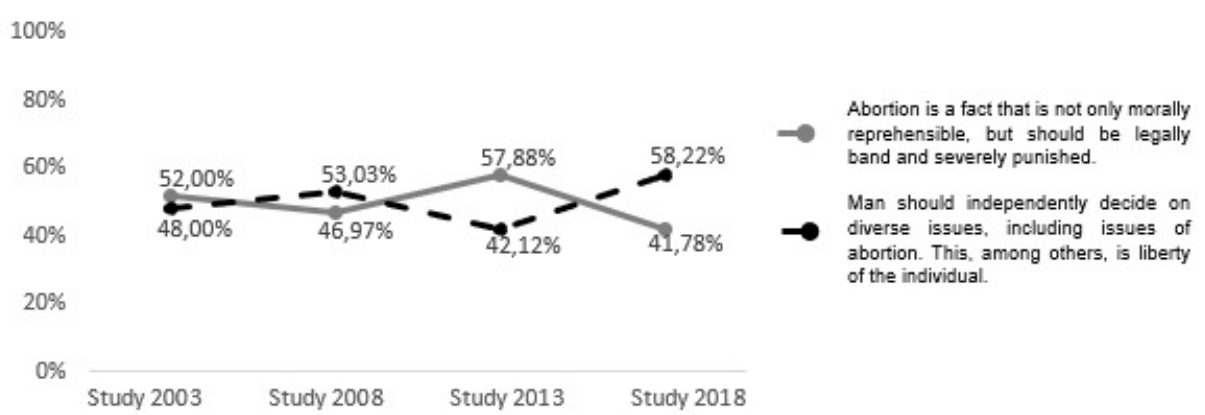

Fig. 8. Comparison of study results from the years 2003, 2008, 2013 and 2018: attitude 8 Source: own work (results of studies from the years 2003 and 2008 were published in: Czerniawska, 2010; 2011)

The issue of permissibility of abortion is the subject of numerous discussions in Poland. Opinions on the matter polarise society, as is seen in the analysis presented below. As it turned out, the subsequent studies recorded the following numbers of opponents of abortion for moral and legal reasons: $52.00 \%, 46.97 \%$, $57.88 \%$ and $41.78 \%$ of students. $48.00 \%, 53.03 \%, 42.12 \%$ and $58.22 \%$ respectively, in turn, viewed such decisions in the categories of personal choice, interpreting it as a sign of personal liberties (conf. fig. 8). Statistically significant differences in the choice of the attitude for this attitude were found when comparing groups for the years 2008 and 2013. The share rose of people who adamantly condemned abortion (a difference of 10.9\%). These were also found when comparing 2018 groups with 2003 and 2013 groups. As it turned out, the share of people representing such views fell (by $10.2 \%$ and $16.1 \%$, respectively.

Controversial opinions were also found with respect to euthanasia. 


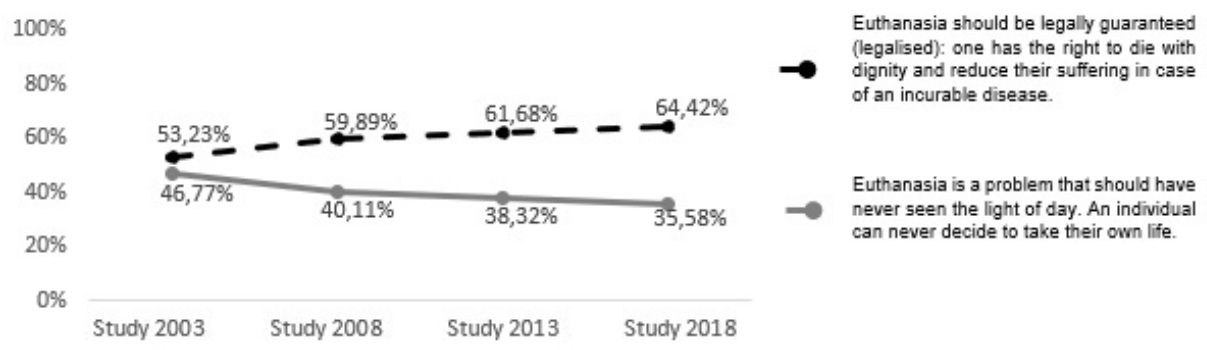

Fig. 9. Comparison of study results from the years 2003, 2008, 2013 and 2018: attitude 9 Source: own work (results of studies from the years 2003 and 2008 were published in: Czerniawska, 2010; 2011)

Students seemed to be divided into two subgroups: opponents of euthanasia ("2003 students" - 46.77\%, "2008 students" - 40.11\%, "2013 students" - 38.32\% and "2018 students" - 35.58\%) and its supporters (53.23\%, 59.89\%, 61.68\% and $64.42 \%$, respectively; conf. fig. 9). Compared to the year 2003, the subsequent three studies saw an increase in the number of people believing that euthanasia should be legalised and that an individual is entitled to a dignified death in case of an incurable illness (in the year 2008 - by $6.7 \%$, in the year 2013 - by $8.4 \%$, and in the year 2018 - by 11.2). The indicated differences were noted with statistical significance (conf. table 1).

\section{Conclusions and summary}

Democracy facilitates the construction of a modern state. The development of democratic institutions in Poland was supposed to facilitate the establishment of social relations on the basis of equality and the achievement of political and personal liberty. It seems natural that ideological considerations would continue to be ever more strongly rooted in civic mentality and contribute to the creation of a specific system.

The objective of the present study was to determine the range of application of the rules of equality and liberty that is substantiated - according to respondents and who should or shouldn't be their addressee. The first of the indicated rules expresses equal rights to activity in various areas (irrespective of e.g. nationality, religious denomination or sexual orientation), the second - autonomy, freedom of activity and greatest possible privacy that is not limited by state intervention (Żardecka-Nowak, 2001). The results were analysed across two dimensions: dominant attitudes were described, and differences between them were evaluated consider- 
ing the criterion of time, meaning - the study year (2003, 2008, 2013 and 2018). It was expected for every subsequent study to see a greater share of students declaring pro-democratic attitudes. Such a hypothesis seemed to be in line with the "logic" of system transformation.

The acquired results mostly indicate high or at least moderate (over 50\% of participants in each survey) approval of democratic rules of equality. Respondents belonging to the four groups spoke mostly in favour of equality of rights for all citizens (attitude 1) as well as national and religious minorities (attitude 2) (percentage indicators of ca. 55-90\%). The three first groups spoke out in favour of creating opportunities for those who are not citizens of the country, e. g. foreigners taking up gainful employment (attitude 3) (percentage indicators ca. 68-80\%). Still, within the group surveyed in the year 2018, this attitude became less popular and characterised $44 \%$ respondents. The provision of equal rights to the homosexual minority was supported by over $50 \%$ of respondents in three studies, and this factor was $46 \%$ only in the year 2013 .

The present study assumes the "optimistic" hypothesis that the acceptance of the rule of equality would rise "study to study". The acquired results, however, do not confirm this assumption, and the comparative analysis indicates more a more complex reality. For the first three views or attitudes, an interesting tendency was observed: the factors were similar if comparisons were made between data collected in the first two studies (2003 and 2008), and significantly lower in the third study (2013), while still lower in the fourth one (2018). The most concise solution could be formulated as follows: Beginning in 2013, relatively more students supported the "reduction" of the equality of citizens not being ethnically Polish or catholic and the reduction of the influx of foreigners. This result is out of line with the hypothesis. The hypothesis was also unconfirmed if the analysis would include the attitude towards homosexual minority rights (attitude 4). As it turned out, in the first survey the share of students supporting such rights was higher than in each subsequent one. This share was also higher in the second survey than in the third one.

Most respondents in the four survey groups supported the democratic rule of freedom, and such forms of its expression as freedom of speech and opinion, even if they are not in line with the views of the government; the right to own initiative and to associate in organisations that are not state-controlled (attitude 5 and 6; percentage indicators ca. 60-95\%). Respondents from the first three groups mostly indicated the necessity of establishment of an open society (attitude 7; percentage indicators ca. 65-83\%). In the fourth group, this attitude was expressed by less than $50 \%$ of respondents. At the same time one must note that in terms 
of civic liberties, those in the political sphere (attitudes 5, 6 and 7 as discussed above), received higher scores than personal liberties (attitudes 8 and 9). This shone through especially in the attitude towards abortion (attitude 8 ; percentage indicators ca. $40-58 \%$ ).

The described study assumed that as the institutions of the democratic state solidify, democratic attitudes would do so as well, a fact shining through in the increase of the share of students accepting the rule of liberty. Did statistically significant differences emerge in the declared attitudes in the four studies? They were not found following a comparative analysis of attitudes towards freedom of speech (attitude 5). The "progress" expected in the hypothesis was found in the attitude towards the right to associate in bodies independent of the state (attitude 6). Still, this right was accepted by a higher proportion of respondents in the last third surveys only if compared to the first one. The comparison of options of attitude 7 , "towards Europe without borders" and "care for the strengthening of independence in economy and defence capacities" revealed interesting interdependencies. The approval of "openness" increased in the year 2008 as compared to 2003, but dropped in the year 2013 as compared to the two preceding surveys. The lowest scores as compared to the three previous groups were found for the year 2018. The results of the comparative analysis fail to confirm the above hypothesis: attitudes either do not change (attitude 5), or changes can only be recorded as compared to 2003 (attitude 6), or alternatively they take the opposite direction to the hypothesised one, in the last three surveys (attitude 7). Comparing data collected in the four dimensions one must note that the right to make independent decisions in terms of abortion was accepted by a higher proportion of students in the last survey as compared to the surveys of the years 2003 and 2013. However, no changes were found in the approval of this view "study to study". What's more, in the year 2013 as compared to the year 2008, the share of students believing that the decision on an abortion should be independent fell (instead of increasing). The right to euthanasia (attitude 9) was - admittedly - approved in later surveys by a higher share of students, but this conclusion refers to specific comparisons, e. g. of the first group with the remaining three. This prevents the confirmation of assumptions expressed in the hypothesis. The achieved study scores indicate that the approval of democracy as a political system need not necessarily "translate" to approval of all its rules and with respect to all people. They also indicate no clear relationship between the progress of democratisation (14, 19, 24 and 29 years) and the approval of the principles of this political system.

What events preceding the subsequent studies could have influenced the attitude towards the rules of equality and liberty? It is worth a look, because experi- 
ences from life in an actually functioning system do not remain without influence on our convictions (Konieczna, 2002). In the years 2000-2003 Poland was going through a recession, and the majority of social strata saw the feeling of fear related to economic existence gaining momentum. The second study followed one of the most significant events in recent history that gave rise to both hopes and fears: In the year 2004 Poland became a member of the European Union, and joined the Schengen agreement in the year 2007, doing away with inspections on the internal borders of state signatories of the document. The years 2004-2007 saw an economic upturn and unemployment rates dropped. The psychological consequence of this state of affairs was the improving optimism of Poles (Gumuła, 2008). One could think that positive social perspectives gaining momentum would translate to positive assessment of the system and improvement in trust in the rules underlying it. This state of affairs shone through in results of the survey of the year 2008, in which students presented pro-democratic attitudes in a relatively greater extent. Referring back to the surveys of the CBOS quoted above (2019) one must also note that the most favourable attitude towards democracy was found in November of 2007 (the statement "democracy is superior to all other forms of government" was confirmed 6.7 times more frequently than denied). The situations preceding the third and fourth survey were decidedly more difficult. In the year 2009, the general public gained access to information on the world economic crisis. Over the subsequent few years (hence, in the period preceding the third study), this crisis strengthened not only the critical stance towards neoliberal rules in the economy, but also translated to the interpretation of the principles of the political system. The bad economic situation of society reduced the possibility of a "favourable" analysis of the problem of civic equality. At that point the "dividing differences" become particularly significant. Referring back again to the CBOS survey (2019), one must note that the least favourable attitudes towards democracy were found in July of 2013 (the statement that "democracy is superior to all other forms of government" was only confirmed 2.9 times more than it was denied; a lower score was only found in the year 2015). Protests of a part of society against Poland signing the ACTA (2012), which could violate the right to information and freedom of speech could be seen as an expression of civic activity.

The years preceding the last of the four surveys brought new experiences. The year 2014 saw the wiretapping affair come to light, which limited trust to the contemporary government. The subsequent year (following parliamentary elections and the formation of the new government) saw changes in the structure of the Constitutional Tribunal of Poland, and a reform of the judiciary was executed. The society divided itself into members/ supporters of the civic movement called 
the Democracy Defence Committee (KOD) and marches in defence of democracy, and their opponents. People reacted in various ways to the so-called black protests against the complete ban on abortions (2016). The issue of migrants in the European Union, including Poland, emerged as well. Foreigners arriving from different cultures were perceived differently from then on. This five-year period was characterised by an increase in interest in political and social issues. It also spawned numerous civic projects and public demonstrations, during which society's views - those more and less democratic - clashed. The question arose again what is democracy, what are its signs and is it given "once and for all"?

It must be stressed that the results of the own work - if viewed as comparisons - give rise to certain disquiet. It is related to the relatively lower approval for the rules of equality inn the last two surveys, as compared to the first two. The conviction that the Polish state should be ruled by Poles for Poles became relatively more attractive; in this view, accordingly, national and religious minorities should submit to the majority. Is hence patriotism aptly delineated against nationalism? What should be the extent of differentiation between one's own group and an alien one, or even the disparagement of others? Students also relatively more frequently support the control of influx of foreigners to Poland. This may be caused not only by economic migrations from the east, but may also be the effect of civic discussions on refugee relocation. It seems "weird", though, if one would consider the numerous, economically motivated excursions of Poles to the west. The problem of equal rights of the homosexual minority is controversial and strongly divides Polish society. This shines through in the marches of supporters and opponents of this equality that tend to be organised.

Poland's accession to the European Union and to the Schengen agreement allowed cooperation and usage of the liberty of "Europe without borders". As it turned out in the last two surveys, more required were moves to strengthen economic independence and the defence capacities of our country. Is it thus so - as the students see it - that expectations related to the EU membership were not done justice to? The studied respondents mostly voted in favour of political freedom (of speech and association). The attitude towards liberties in terms of personal decisions is not so clear - this applies to euthanasia, and abortion in particular. These two views enjoy a specific status, though. As the CBOS study (2016) showed, they are largely dependent on the attitude towards religion, the teachings of the Church and participation in religious practices. They are also tied to one's system of values (Czerniawska, 2013).

The analysis of events - political choices, protests, demonstrations, acts of law - begs the question about the future condition of the rules of equality and 
liberty in the next generation of students? A response to this question shall be provided by the survey planned for 2023. One should however keep in mind the fact that - as Z. Bauman believes (onet.wiadomości, 2014) - that people across the world are starting to lose faith in the democratic system as it does not hold on to its promises. The issue of inequality is becoming more and more clear; this is the result of the crisis of the welfare state, social institutions and of labour authorities. The question arises ever more frequently about equality: but equality of what ( $\mathrm{Fi}$ toussi, Rosanvallon, 2002: Sen, 2002); political systems are in turn analysed with consideration of economic circumstances. Poverty limits liberty. The utilisation of the spoils of democracy and the development of one's own life becomes doubtful in such a case.

\section{Bibliography}

Bartkowski J., Jasińska-Kania A. (2002), Organizacje dobrowolne a rozwój społeczeństwa obywatelskiego, [in:] A. Jasińska-Kania, M. Marody (eds.), Polacy wśród Europejczyków. Wartości społeczeństwa polskiego na tle innych krajów europejskich, Warszawa.

Beetham D., Boyle K. (1994), Demokracja. Pytania i odpowiedzi, trans. T. Jasudowicz, Toruń.

Czerniawska M. (2010), Zmiany wartości i postaw młodzieży w okresie przeobrażeń ustrojowych. Kolektywizm versus indywidualizm. Studium interdyscyplinarne, Białystok.

Czerniawska M. (2011), Za jaką równością i wolnością jesteśmy? - analiza porównawcza postaw studentów diagnozowanych w latach 2003 i 2008, Pedagogika Społeczna, vol. 40.

Czerniawska M. (2013), Postawy w stosunku do aborcji i eutanazji, Pedagogika Społeczna, vol. 50.

Dahl R.A. (1995), Demokracja i jej krytycy, trans. S. Amsterdamski, Kraków.

Dopuszczalność aborcji w różnych sytuacjach. Komunikat $z$ badań Nr 71/2016, cbos.pl/SPISKOM. POL/2016/K_071_16.PDF, accessed: 29.07.2019.

Fitoussi J-P., Rosanvallon P. (2002), Czas nowych nierówności, trans. S. Amsterdamski, Kraków.

Frąckowiak-Sochańska M. (2009), Preferencje ładów normatywnych kobiet wobec wartości w Polsce na przełomie XX i XXI wieku, Poznań.

Gumuła W. (2008), Teoria osobliwości społecznych. Zaskakująca transformacja w Polsce, Warszawa.

Konieczna J. (2002), Wartości polityczne w okresie transformacji w Polsce, na Ukrainie i innych krajach Europy Wschodniej, [in:] A. Jasińska-Kania, M. Marody (eds.). Polacy wśród Europejczyków. Wartości społeczeństwa polskiego na tle innych krajów europejskich, Warszawa.

Krzemiński I. (2005), Społeczeństwo obywatelskie i symbole wspólnoty, [in:] M. Drogosz (ed.), Jak Polacy przegrywaja. Jak Polacy wygrywaja, Gdańsk.

KT (2016), Zygmunt Bauman w "El Pais": mamy do czynienia z kryzysem demokracji, http://wiadomosci.onet.pl/swiat/zygmunt-bauman-w-el-pais-mamy-do-czynienia-z-kryzysem-demokracji/p6vbe4, accessed: 24.06.2019.

Ludwikowski R.R. (1998), Demokracja, [in:] Encyklopedia socjologii, Warszawa.

Polacy o demokracji. Komunikat z badań Nr 68/2019, cbos.pl/SPISKOM.POL/2019/K_068_19.PDF, accessed: 24.06.2019. 
Radziewicz-Winnicki A. (2008), Pedagogika społeczna w obliczu realiów codzienności, Warszawa.

Reykowski J. (1995), Subiektywne znaczenia pojęcia "demokracja” a ujmowanie rzeczywistości politycznej, [in:] J. Reykowski (ed.), Potoczne wyobrażenia o demokracji. Psychologiczne uwarunkowania i konsekwencje, Warszawa.

Reykowski J. (ed.) (1993), Wartości i postawy Polaków a zmiany systemowe. Szkice z psychologii politycznej, Warszawa.

Sen A. (2002), Nierówności. Dalsze rozważania, trans. I. Topińska, Kraków.

Wasilewski J. (2005), Ideał demokracji i jego wcielenia, [in:] U. Jakubowska, K. Skarżyńska (eds.), Demokracja w Polsce - doświadczenie zmian, Warszawa.

Żardecka-Nowak M. (2001), Czy wspótczesna liberalna demokracja potrzebuje fundamentów filozoficznych? [in:] M. Szulkiewicz (ed.), Filozofia i polityka, Kraków. 
